\title{
Social functioning and peer relationships in children and adolescents with chronic pain: A systematic review
}

\author{
Paula A Forgeron RN MN ${ }^{1}$, Sara King $\mathrm{PhD}^{1}$, Jennifer N Stinson RN NP-Peds $\mathrm{PhD}^{2}$, \\ Patrick J McGrath PhD OC ${ }^{1}$, Amanda J MacDonald BSc${ }^{1}$, Christine T Chambers PhD ${ }^{1}$
}

PA Forgeron, S King, JN Stinson, PJ McGrath, AJ MacDonald, CT Chambers. Social functioning and peer relationships in children and adolescents with chronic pain: A systematic review. Pain Res Manage 2010;15(1):27-41.

BACKGROUND: Peer relationships during childhood and adolescence are acknowledged to be negatively impacted by chronic pain; however, to date there has been no synthesis of this literature.

OBJECTIVE: To systematically review existing literature describing the social functioning and peer relationships in children and adolescents with recurrent or continuous chronic pain.

METHODS: Articles on peer relationship factors studied in samples of children and adolescents with chronic pain published in English or French were identified using EMBASE, Medline, CINAHL and PsycINFO. Two independent reviewers performed initial screenings using study titles and abstracts, and reviewed each eligible article in full.

RESULTS: Of 1740 published papers yielded by the search, 42 articles met the inclusion criteria and were included in the present review. Nine studies had peer relationship investigation as the primary purpose of the study; the remaining 33 examined peer relationships as part of a broader study. A range of specific and more general measures was used to examine peer relationships. Across studies, children and adolescents with chronic pain were reported to have fewer friends, be subjected to more peer victimization, and were viewed as more isolated and less likeable than healthy peers.

CONCLUSIONS: Children and adolescents with chronic pain have peer relationship deficiencies. However, the majority of studies to date measure peer relationships as part of a broader study and, thus, little attention has been paid specifically to peer relationships in this group. Additional research examining the quality of peer relationships of children and adolescents with chronic pain, as well as development of measures specifically designed to assess these relationships, is needed.

Key Words: Adolescent; Chronic pain; Pediatric pain; Peer relationships; Systematic review

\section{Le fonctionnement social et les relations avec les camarades des enfants et des adolescents ayant des douleurs chroniques : Une analyse systématique}

HISTORIQUE : On sait que, pendant l'enfance et l'adolescence, la douleur chronique peut nuire aux relations avec les camarades. Cependant, il n'existe pas encore de synthèse des publications sur le sujet.

OBJECTIF : Procéder à l'analyse systématique des publications qui décrivent le fonctionnement social et les relations avec les camarades chez les enfants et les adolescents ayant des douleurs chroniques récurrentes ou continues.

MÉTHODOLOGIE : Les auteurs ont trouvé des articles sur les facteurs des relations avec les camarades étudiés sur des échantillons d'enfants et d'adolescents ayant des douleurs chroniques, publiés en anglais ou en français, grâce à EMBASE, Medline, CINAHL et PsycINFO. Deux analystes indépendants ont procédé à la sélection initiale au moyen des titres et des résumés des études et ont révisé l'intégralité de chaque article admissible.

RÉSULTATS : Sur les 1740 articles publiés colligés grâce à la recherche, 42 respectaient les critères d'inclusion et ont fait partie de la présente analyse. Neuf avaient comme principal objectif l'exploration des relations avec les camarades, et les 33 autres incluaient ces relations dans le cadre d'une étude plus vaste. Une série de mesures précises et plus générales permettaient d'examiner les relations avec les camarades. Dans les études, on indiquait que les enfants et les adolescents ayant des douleurs chroniques avaient moins d'amis, étaient davantage soumis à la victimisation par leurs camarades et étaient davantage perçus comme isolés et moins sympathiques que leurs camarades en bonne santé.

CONCLUSIONS : Les enfants et les adolescents ayant des douleurs chroniques ont des carences dans leurs relations avec les camarades. Cependant, la majorité des études jusqu'à maintenant mesurent les relations avec les camarades dans le cadre d'une étude plus vaste et, par conséquent, accordent peu d'attention à ce type de relation au sein de ce groupe. Il faut mener d'autres recherches sur la qualité des relations des enfants et des adolescents ayant des douleurs chroniques avec leurs camarades et élaborer des mesures conçues pour évaluer ces relations.

have been found to act as a buffer in children who have negative family relationships (2), as well as provide protection against the negative effects of peer victimization (3). In 2003, Nangle et al (4) found that positive dyadic friendship experiences protect against loneliness and depression in elementary school-aged children.

Difficulties with peer relationships have been acknowledged as one of the major social ramifications of chronic pain in been found to serve a protective function when the individual is confronted with difficulties (2-4). Reciprocal friendships

${ }^{1}$ Dalhousie University and IWK Health Centre, Halifax, Nova Scotia; ${ }^{2}$ University of Toronto and The Hospital for Sick Children, Toronto, Ontario

Correspondence: Ms Paula A Forgeron, Pediatric Complex Pain Service, IWK Health Centre, PO Box 9700, 5850/5980 University Avenue, Halifax, Nova Scotia B3K 6R8. Telephone 902-448-0749, fax 902-470-7911, e-mail pforgero@dal.ca 
adults $(5,6)$. This is not surprising, given that chronic pain is an insidious condition that can negatively impact all aspects of an individual's life. Adults with chronic pain have been found to experience self-imposed isolation due to the embarrassment of their pain disability (6). Additionally, in 2007, Smith and Osborn (5) found that adults with chronic low back pain use self-isolation as a negative coping mechanism. Individuals with chronic pain withdraw from social contact with peers rather than attempt to conceal their discomfort in social situations. Once isolated, interacting with others becomes more difficult, leading some to view themselves as having no social value. Adults with chronic pain may receive fewer social invitations as a result of their changing personality due to pain and because of other's discomfort about the amount of pain the person is experiencing while socializing (6). There is no evidence that the situation is any different for children and adolescents with chronic pain.

Qualitative research suggests that peer relationships are both a source of stress and support for adolescents who live with chronic pain $(7,8)$, and the pain condition may interfere with their ability to maintain friendships (8). Using a focus group interview method in 2008, Forgeron and McGrath (7) asked adolescents with chronic pain to describe daily coping needs related to pain. Results indicated that all participants had experienced negative peer relations in some manner since developing chronic pain (eg, verbal assaults or loss of friendship), but the emotional support and companionship of their remaining friends was helpful in coping with their pain. In a similar study in 2002, Carter et al (8) used a range of methods to examine friendships in adolescents with chronic pain and found that the majority of participants had experienced loss of friendships as a result of having chronic pain. Participants made the distinction between 'sunny day friends' (ie, friends who would come and go) and 'proper friends' (ie, friends who were always available to provide support). Participants also indicated that pain was often problematic in maintaining friendships, as a direct result of being unable to participate in activities with peers and missed school days. In 2002, Sällfors et al (9) used individual interviews with children and adolescents with juvenile chronic arthritis to examine the life situation for these participants. These children and adolescents reported that their pain resulted in negative attitudes from others, which made them feel sad, left out and angry. Across these qualitative studies, participants often indicated that peers did not understand their pain conditions.

Although epidemiological studies $(10,11)$ indicate that $25 \%$ to $31 \%$ of children and adolescents experience chronic pain at some point in their childhood or adolescence, only one-third of these children and adolescents experience disabling chronic pain (10). Despite the importance of peer relationships during childhood and adolescence, and the negative impact chronic pain may have on these relationships, no formal synthesis of this literature has been conducted to date. Therefore, it is essential to review and synthesize the existing literature in this area to understand current knowledge about peer relationships in youth with chronic pain - areas in which further investigation and implications for clinical practice are required. The purpose of the current review is to investigate the social functioning and peer relationships of children and adolescents with chronic pain.

\section{METHOD}

Data sources

Key electronic database searches (EMBASE, Medline, CINAHL and PsycINFO) were conducted by a librarian information specialist using the following search terms: child, adolescent, chronic pain, pain, disability, peer relationships, friendships, school functioning, social functioning, social inclusion, teachers, abdominal pain, headache, migraine, sickle cell disease, arthritis, juvenile fibromyalgia, musculoskeletal pain, and neuropathic pain. The reference lists for each included article were searched by hand to ensure that relevant papers were not missed; two papers were included based on this hand search. An anonymous reviewer suggested two other papers, and one additional paper was identified in the course of retrieving these papers. Two independent reviewers (PF, SK) performed an initial screening using study titles and abstracts. For the databases, reviewers recorded the following details: number of studies found, number meeting inclusion criteria, number excluded, reason for exclusion and whether the article had to be obtained to determine eligibility. Articles that were excluded by one reviewer but included by another were included or excluded based on consensus, with disagreements settled by a third reviewer (the third reviewer was not required). After an agreement on eligibility was reached, the same two independent researchers reviewed each article in full to determine the significant peer relationship findings in each study.

\section{Inclusion and exclusion criteria}

The inclusion criteria included peer-reviewed primary quantitative research articles published in English or French between 1988 and 2008, studies of children and/or adolescents with any type of chronic pain (recurrent pain characterized by episodes of pain followed by periods of no pain or continuous pain characterized by ongoing daily pain with and without exacerbations of intensity), and outcome measures of peer relationships, friendships, social functioning, pain or disability. Review articles, commentaries, books, book chapters, dissertations and qualitative research articles were excluded. Although dissertations are primary studies, they were excluded due to retrieval difficulties; inclusion of dissertation evidence has been rarely found to impact the conclusions of a review (12).

\section{Data extraction}

Data were extracted by the first two authors using customized forms specifying author, type of study, sample (age of children, type of pain), number of participants, measures used, primary outcomes and primary results. Due to the varied nature of the studies (correlation, descriptive and cohort), methodological rigor was not assessed because bias issues vary in each of these research designs. No intervention studies or randomized controlled trials were found. Studies meeting inclusion criteria were categorized according to their primary focus: peer relationships (ie, the primary focus was to assess various peer relationship factors for children and adolescents with chronic pain), quality of life, mental health factors (eg, anxiety and depression) and 'other'. The 'other' category consisted of studies that included diverse primary focuses such as exploring mothers' attributions for their child's pain, as well as large survey studies exploring risk factors for various types of chronic pain in children and adolescents, but included some relevant 
data on peer relationships or social functioning. Each study was reviewed and summarized based on its primary focus, type of social relationship assessed (eg, peers or close friends), rater (ie, self, peer or other), component of peer relationship assessed (ie, quantity or quality), measure used, child factors impacting peer relationships (eg, anxiety, depression), and the extent of pain or pain-related disability.

\section{RESULTS}

\section{Description of studies}

The electronic database search yielded 1740 possible studies, with 193 duplicate articles, as well as 27 books, book chapters and/or dissertations. Based on abstract review, 1516 studies were excluded and 135 studies were retrieved for further review. After a preliminary review of the 135 studies, 42 met the a priori review criteria and were included in the present review.

Studies meeting inclusion criteria varied widely in primary focus and design. Only nine studies investigated peer relationships as the primary focus. The other 33 studies assessed peer relationships by using measures that included some form of social functioning scale or subscale of a global measure. Given the variety of studies included in the present review (ie, descriptive studies, correlation studies and studies with a variety of goals) (13), a quantitative meta-analysis was not possible; therefore, a descriptive analysis and synthesis of the findings is presented.

\section{Primary focus: Peer relationships}

As shown in Table 1, nine studies specifically explored peer relationships of children and adolescents with various chronic pain conditions (eg, headaches and recurrent abdominal pain [RAP]). Given that these studies specifically examined the association between peer relationships and chronic pain, results will be described in more depth because this is the primary goal of the present review. The findings from all but two of these studies suggested that the presence of chronic pain has a negative effect on peer relationships. Six of these studies included healthy comparison groups (14-19), with five of these suggesting that children with chronic pain differ from typical children with respect to peer relationships (14,16-19). In 2007, Greco et al (14) found that children and adolescents with RAP were subjected to more overt and relational self-reported victimization than healthy peers, and that this victimization was especially prevalent in boys with RAP. Victimization rates were also positively correlated with the number of pain sites (ie, headache, stomach ache or backache) in a descriptive schoolbased study of children and adolescents (20).

Five studies in this category used self- and peer-report measures to examine peer relationships of children and adolescents with juvenile idiopathic arthritis (JIA) (15), juvenile fibromyalgia syndrome (JFS) (18), sickle cell disease (SCD) $(16,17)$ and migraine (19). Children were asked to provide reports about reciprocal friendships, best friends and likeability of peers (Table 1). Only one (15) of these five studies found no peer relationship differences on these classroom measures for children and adolescents with JIA compared with matched healthy classmates, regardless of disease severity. The other four studies found that children and adolescents with other painful chronic conditions were experiencing peer relationship difficulties when compared with matched healthy classmates.
In 2007, Kashikar-Zuck et al (18) found that adolescents with JFS were rated as more isolated and sensitive by peers and themselves, less disruptive or aggressive by teachers, less popular among their peers, and less likely to exhibit leadership skills. Children and adolescents who suffered from migraines also had fewer reciprocal friendships than healthy children (19), with younger children faring worse than adolescents on peer relationship measures. Younger children with migraines were found to be twice as likely to not have any reciprocal friendships and they also received fewer best friend nominations than younger children without migraines, and middle school children with and without migraines.

Two studies by Noll et al, one from 1996 (17) and one from 2007 (16), indicated that peers viewed children and adolescents with SCD differently, in that they had fewer reciprocal friendships and received fewer best friend nominations than typical children. However, there were some inconsistencies across these studies. For example, in the earlier study, sex differences were noted, in that girls with SCD were chosen less often as a best friend and had fewer reciprocal friendship nominations than boys with SCD and healthy controls. On the other hand, boys with SCD were considered by their classmates to be less aggressive than healthy children. However, findings in the 2007 study indicated that children and adolescents with SCD were chosen less often as a best friend and had fewer reciprocal friendship nominations, although they were not perceived as being less likeable. In a 2004 study of social anxiety among children and adolescents with SCD, Wagner et al (21) found that higher pain intensity was associated with greater overall social anxiety in older children and adolescents with SCD, but not in younger children. Results indicated an interaction between pain and age, such that older children experiencing greater pain feared negative evaluation by others.

Only one study (22) in this category examined attitudes and beliefs of healthy children toward hypothetical peers with pain. In 2000, Guite et al (22) used vignettes depicting boys and girls with and without organic causes for their abdominal pain and asked healthy participants to respond to a series of questions related to the hypothetical peer. Regardless of the hypothetical child's sex, both girls and boys considered organic disease to be more severe, although this did not affect the likeability of the vignette character. There was a same-sex preference with respect to the likeability of the hypothetical peer, which is developmentally appropriate given the age of the participants (fourth and fifth graders).

In summary, the majority of studies within this category suggest that establishing peer relationships can be challenging for children and adolescents with a chronic pain condition. Some of the studies in this category examined general peer relationships as opposed to reciprocal friendships. Even those that did examine reciprocal friendships (15-19) focused on the number of reciprocal friendships from a class list rather than the quality of these friendships. However, in these studies, the actual number of reciprocal friendship nominations, best friend nominations or likeability ratings were not provided, meaning that it is difficult to ascertain how many fewer friends children and adolescents with chronic pain have. Given that none of the included studies evaluated friendship quality, it is difficult to draw conclusions regarding the perception of friendship quality among youth with chronic pain. 
TABLE 1

Studies with a primary focus on peer relationships

\begin{tabular}{|c|c|c|}
\hline $\begin{array}{l}\text { Author, year } \\
\text { (reference), country, } \\
\text { study type }\end{array}$ & Sample, age, sex & Measures \\
\hline $\begin{array}{c}\text { Greco et al, } 2007 \text { (14), } \\
\text { USA, case-control } \\
\text { comparison study }\end{array}$ & $\begin{array}{l}n=120 ; \text { RAP, } n=60 ; \\
\quad \text { healthy controls, } n=60 \\
12.3 \pm 1.19 \text { years } \\
41 \text { girls }\end{array}$ & $\begin{array}{l}\text { Child: Abdominal Pain Index, use of school } \\
\text { medical services. Peers: Children's Social } \\
\text { Experiences Questionnaire - Peer Report. } \\
\text { Teachers: Social Skills Rating Scale }\end{array}$ \\
\hline $\begin{array}{c}\text { Guite et al, } 2000 \text { (22), } \\
\text { USA, vignette study }\end{array}$ & $\begin{array}{l}\text { Healthy children rating } \\
\text { vignette characters } \\
\text { with organic and } \\
\text { nonorganic RAP, } \\
n=363 \\
10.15 \pm 0.76 \text { years } \\
52 \% \text { girls }\end{array}$ & $\begin{array}{l}\text { Child: Study-designed questionnaire: } \\
\text { Likeability - } 5 \text { items regarding how much the } \\
\text { child liked the vignette character; severity - } \\
2 \text { items regarding perceived symptom severity } \\
\text { of the vignette character; relief from } \\
\text { responsibility - } 4 \text { items regarding extent that } \\
\text { the vignette character should be relieved from } \\
\text { responsibilities }\end{array}$ \\
\hline
\end{tabular}

Kashikar-Zuck et al, $\quad n=110 ;$ JFS, $n=55$; 2007 (18), USA, matched classmates, case-control study $\quad \mathrm{n}=55$

12-18 years

52 girls with JFS and 52 matched female peers

Natvig et al, 2001 (20), n=856

Norway, correlation 10-15 years

study 423 boys

Noll et al, 2000 (15), $n=148$; JRA, n=74; USA, case-control matched classmates, study

$\mathrm{n}=74$

8-14 years

40 girls and 34 boys with JRA (sex-matched classmates)

Noll et al, 2007 (16), USA, case-control study

$\mathrm{n}=86$; SCD, $\mathrm{n}=43$; matched classmates, $\mathrm{n}=43$

8-15 years

26 girls with SCD and 26 healthy female classmates

Noll et al, 1996 (17), $\quad n=68 ; S C D, n=34$; USA, case-control matched classmates, study
Adolescents (JFS and controls): RCP, TBF, LRS, 9 additional items to assess nonsocial attributes that may be impacted by chronic illness. Teachers: Teacher RCP

Child: Questions related to presence of psychosomatic symptoms (headache, backache, stomach ache and dizziness), bullying experience, self-efficacy, social support (specifically from teachers and peers) and decision control, and school alienation and distress

Parent: CBCL, DOTS-R. Children: JRA patients No differences on peer relationship measures (RCP, TBF, and controls - RCP, TBF, LRS; JRA patients only - CDI, Roberts Apperception Test for Children, LSDQ, SPPC, Wechsler Intelligence Scale for Children - Revised. Teacher: RCP

Parent: Demographic questionnaire, DOTS-R. Children: RCP, TBF, LRS, CDI, LSDQ, SPPC. Teacher: RCP

Parent: Demographic background questionnaire, DOTS-R. Children: RCP, TBF, LRS plus 3 questions on who is sick most often, tired most often and misses the most school, LSDQ, SPPC, CDI, Roberts Apperception Test for Children, block design and vocabulary subtests of the Wechsler Intelligence Scale for Children - Revised. Teacher: RCP and student absenteeism. Researcher: Chart review for disease severity
Findings

In children with RAP, victimization > controls. Modest support for peer victimization moderating relationship between pain and school functioning

Children with organic disease seen as having more severe disease and pain. Boys and girls viewed RAP in boys as being more severe. Regardless of RAP type, same-sex preferences for likeability. Presence of stressors in vignettes did not impact liking ratings. Severity of symptoms mediated the relationship in some cases. Boys granted $\uparrow$ relief of responsibility to girls with organic RAP; boys granted all RAP boys equal relief from responsibility; girls granted nonorganic RAP girls $\uparrow$ responsibility relief (unexpected finding) but not boys with nonorganic RAP

Teens with JFS rated as sensitive/isolated > peers by peers and self. JFS patients viewed as demonstrating popular/ leadership behaviours < by peers and self. Received $\downarrow$ best friend nominations. Viewed $\downarrow$ aggressive/disruptive by teachers

Those who were bullied sometimes or more often had $\uparrow$ rates of feeling low compared with any other psychosomatic symptom and/or group. Odds were > for bullied children to experience all 3 forms of pain compared with nonbullied peers. The odds of experiencing all 3 pains $\uparrow$ as bullying $\uparrow$

LRS) among teacher, JRA and classmates. Mothers of children with mild JRA ( $53 \%$ of sample) perceived their children as being more socially competent on $C B C L$ versus more active disease. Fathers rate children with mild JRA with $\downarrow$ total behaviour problems on the CBCL versus children with active disease

Teachers rated students with SCD as $\uparrow$ prosocial and $\downarrow$ aggressive. Children with SCD chosen $\downarrow$ as a best friend and had $\downarrow$ reciprocal friendship nominations by peers but were not less well liked. Children with SCD viewed as $\uparrow$ sick, $\uparrow$ absent from school, and $\downarrow$ athletic by peers; overall $\uparrow$ sickness did not mediate a path between illness and outcomes for SCD on best friend or reciprocal friendship nominations

Girls with SCD viewed as $\downarrow$ sociable and/or displaying fewer leadership behaviours, chosen $\downarrow$ often as a best friend, received $\downarrow$ reciprocal friendship nominations and viewed as less acceptable. Boys with SCD viewed as $\downarrow$ aggressive. Compared with peers, children with SCD viewed as $\uparrow$ sick, $\uparrow$ absent from school and 'being tired a lot' compared with peers. Trend for older children with SCD to report $\uparrow$ loneliness. Frequency of pain episodes captured in rating of severity of SCD (along with number of complications, major organ involvement and number of hospitalizations) was not a significant factor 
TABLE 1 - CONTINUED

Studies with a primary focus on peer relationships

\begin{tabular}{|c|c|c|c|}
\hline $\begin{array}{l}\text { Author, year } \\
\text { (reference), country, } \\
\text { study type }\end{array}$ & Sample, age, sex & Measures & Findings \\
\hline $\begin{array}{l}\text { Vannatta et al, } 2008 \\
\text { (19), USA }\end{array}$ & $\begin{array}{l}\text { n=138; migraine, } n=69 ; \\
\text { matched classmates, } \\
\text { n=69 } \\
\text { 8-14 years } \\
31 \text { girls with migraine } \\
\text { and } 31 \text { female } \\
\text { classmates }\end{array}$ & Child: RCP, TBF, LRS. Teachers: RCP & $\begin{array}{l}\text { Children with migraine had } \downarrow \text { reciprocated friendships. Younger } \\
\text { children received } \downarrow \text { best friend nominations and were twice } \\
\text { as likely not to have any reciprocated friendships versus } \\
\text { peers and middle school participants with and without } \\
\text { migraine. Boys with migraine viewed as } \downarrow \text { aggressive and } \\
\downarrow \text { disruptive. Middle school participants with migraine viewed } \\
\text { as exhibiting } \uparrow \text { leadership behaviours. Teachers rated } \\
\text { participants with migraine as } \downarrow \text { aggressive and disruptive. No } \\
\text { correlations between migraine frequency or pain intensity } \\
\text { and friendship measures }\end{array}$ \\
\hline $\begin{array}{l}\text { Wagner et al, } 2004 \\
\text { (21), USA, } \\
\text { correlation study }\end{array}$ & $\begin{array}{l}n=58 \text { SCD patients } \\
8-17 \text { years } \\
57 \% \text { girls }\end{array}$ & $\begin{array}{l}\text { Parent: Demographic questionnaire (locally } \\
\text { designed). Child: Social Anxiety Scale for } \\
\text { Children - Revised, VAS pain intensity rating. } \\
\text { Medical records: SCD type, disease severity, } \\
\text { hemoglobin }\end{array}$ & $\begin{array}{l}\text { Mean }( \pm \text { SD) pain intensity } 61.24 \pm 29.96 \text { on a } 100 \mathrm{~mm} \text { VAS. } \\
\text { Severe pain ratings associated with } \uparrow \text { overall social anxiety } \\
\text { in older children and adolescents but not younger children. } \\
\text { Pain } \times \text { age associated with } \uparrow \text { fears of negative evaluation by } \\
\text { others. Pain } \times \text { age not associated with social avoidance and } \\
\text { distress for new situations or in general situations }\end{array}$ \\
\hline
\end{tabular}

In studies with a primary focus on peer relationships, the aim was to explore some aspect of peer relationships. Age data presented as mean \pm SD or range in years. CBCL Child Behavior Checklist; CDI Child Depression Inventory; DOTS-R Revised Dimensions of Temperament Survey; JFS Juvenile fibromyalgia syndrome; JRA Juvenile rheumatoid arthritis; LRS Like rating scale; LSDQ Loneliness and Social Dissatisfaction Questionnaire; RAP Recurrent abdominal pain; RCP Revised Class Play; SCD Sickle cell disease; SPPC Self-Perception Profile for Children; TBF Three best friends; VAS Visual analogue scale

\section{Primary focus: Quality of life}

Fifteen of the studies selected for inclusion were classified as being primarily focused on quality of life in children and adolescents experiencing chronic pain (Table 2). These studies used a variety of measures to assess quality of life, making direct comparisons between studies difficult. Six of the 15 studies examined the quality of life of children and adolescents experiencing various types of headaches, such as tension-type, chronic daily headaches and migraines (23-28). Based on an examination of social subscale scores, four of these six studies found that quality of life was negatively impacted by the presence of chronic pain. Findings of the 2006 study by Strine et al (27) are of particular note because these authors detailed the type of social difficulties faced by children with headaches. According to parent report on the extended version of the Strengths and Difficulties Questionnaire (27), children with headaches were 3.3 times more likely to face difficulties in friendships, 2.0 times more likely to play alone, 2.6 times more likely to be victimized by others and 1.3 times as likely to relate better to adults, compared with normative data. This being said, not all studies in this domain found significant differences in quality of life for youth with chronic headache. Specifically, studies by Bandell-Hoekstra et al (23) in 2002 and Langeveld et al (25) in 1997 examined quality of life using the Quality of Life Headache in Youth scale and found no difference in social interaction with peers for children and adolescents with headaches, regardless of severity.

Three of the studies (29-31) with a quality of life focus examined the impact of arthritis on quality of life in children and youth. Results from all three studies indicated that social activities were negatively impacted as a result of arthritic pain, but this impact varied considerably depending on pain symptoms. For example, in a two-week study period, $44 \%$ of participants reported no impact on their social activities due to arthritis; however, for $12 \%$ of the participants, social activities decreased up to $40 \%$ on days with excessive pain symptoms (30).

Results supporting impaired peer relationships when assessing quality of life were reported in the four studies that examined heterogeneous chronic pain populations. All four of these studies (32-35) found a negative relationship between the presence of chronic pain and social functioning in terms of increased limitations in family, social and academic activities among children with chronic pain. In 2003, Merlijn et al (35) also found that adolescent participants with chronic pain had poorer quality of life in all measured domains, including less social acceptance by others, than healthy peers, suggesting that other types of peer-related social functioning apart from activity may be negatively impacted by chronic pain.

The two studies $(36,37)$ that examined the impact of SCD pain on quality of life in children and adolescents suggest that SCD pain negatively affects social functioning, primarily by interfering with participants' engagement with school and leisure activities, but that this negative effect was not uniform for all participants (37). A 1989 investigation by Hurtig et al (37) concluded that SCD negatively impacted peer relationships in adolescent boys, whereas girls or younger boys were not affected to the same degree. These authors suggest that this finding may be influenced by the physically active nature of interactions between adolescent boys compared with girls and younger boys.

Overall, the studies reported that having a chronic pain condition negatively impacted an individual's quality of life, due to missing out on social activities with peers and, thus, decreasing opportunities to interact with peers and build friendships. Given the nature of the measures used in these studies, it is difficult to accurately determine the extent to which the decrease in social activities impacts the peer relationships of these children and adolescents. 
TABLE 2

Studies with a primary focus on quality of life

\begin{tabular}{|c|c|c|c|}
\hline $\begin{array}{l}\text { Author, year (reference), } \\
\text { country, study type }\end{array}$ & Sample, age, sex & Measures & Findings \\
\hline $\begin{array}{l}\text { Bandell-Hoekstra et al, } 2002 \\
\text { (23), Netherlands, cross- } \\
\text { sectional study }\end{array}$ & $\begin{array}{l}\mathrm{n}=2815 \text {; low } \mathrm{HA}, \mathrm{n}=605 ; \\
\quad \text { medium HA, } \mathrm{n}=1626 \text {; severe } \\
\mathrm{HA}, \mathrm{n}=342 ; \mathrm{HA} \text { free, } \mathrm{n}=242 \\
\text { 9-16 years } \\
\text { Sex not specified }\end{array}$ & $\begin{array}{l}\text { Child: Waters Headache Questionnaire, Paediatric } \\
\text { Pain Assessment Tool, PCQ, QLH-Y }\end{array}$ & $\begin{array}{l}\text { No significant difference between the } 3 \mathrm{HA} \\
\text { groups with regard to social interaction with } \\
\text { peers and/or school functioning }\end{array}$ \\
\hline $\begin{array}{l}\text { Bennett et al, } 2000(32) \text {, } \\
\text { Canada, descriptive study }\end{array}$ & $\begin{array}{l}\mathrm{n}=43 \text { nonspecific chronic pain } \\
\text { patients; no controls } \\
\text { 7-16 years } \\
35 \text { girls and } 8 \text { boys }\end{array}$ & $\begin{array}{l}\text { Parent: Survey developed specifically for their clinic } \\
\text { and captured pain interference with social/leisure } \\
\text { activities outside of school }\end{array}$ & $\begin{array}{l}35 \% \text { of parents reported that their child had a } \\
\downarrow \text { in their social/leisure activities }\end{array}$ \\
\hline $\begin{array}{l}\text { Brna et al, } 2008 \text { ( } 24) \text {, } \\
\text { Canada, case-comparison } \\
\text { study }\end{array}$ & $\begin{array}{l}\text { n=994 HA patients; migraine } \\
\text { 9.3\%, mood disorders } 2.1 \% \text {, } \\
\text { anxiety disorders } 1.8 \% \\
\text { 12-19 years } \\
\text { 48.7\% female }\end{array}$ & $\begin{array}{l}\text { Child: Medical Outcomes Study 36-item Short Form } \\
\text { Health Survey }\end{array}$ & $\begin{array}{l}\text { HA, independent of mood or anxiety, } \\
\text { negatively impacted quality of life including } \\
\text { the social subscale }\end{array}$ \\
\hline $\begin{array}{l}\text { Gil et al, } 2003(36), \text { USA, } \\
\text { correlation study }\end{array}$ & $\begin{array}{l}\mathrm{n}=37 \text { SCD patients, no } \\
\text { controls } \\
13-17 \text { years } \\
13 \text { boys }\end{array}$ & $\begin{array}{l}\text { Child: Daily diary (sections on pain, school and } \\
\text { other activities, stress, mood), Adolescent Daily } \\
\text { Hassles Scale, Symptom Checklist } 90 \text { - Revised, } \\
\text { Global Severity Index }\end{array}$ & $\begin{array}{l}\uparrow \text { same-day pain associated with same-day } \\
\text { negative mood. Same-day improved pain } \\
\text { associated with same-day positive mood. } \\
\text { No comment on type of stressor in analysis } \\
\text { of daily stressors (daily stressors included } \\
\text { friends, family, teachers, school and work) }\end{array}$ \\
\hline $\begin{array}{l}\text { Hurtig et al, } 1989 \text { (37), USA, } \\
\text { found by hand, correlation } \\
\text { study }\end{array}$ & $\begin{array}{l}n=70 \text { SCD patients } \\
8-16 \text { years } \\
37 \text { girls }\end{array}$ & $\begin{array}{l}\text { Parent: Structured interview designed for study, } \\
\text { CBCL. Child: Structured study interview, Wechsler } \\
\text { Intelligence Scale for Children - Revised, } \\
\text { California Test of Personality. Teacher: } \\
\text { Questionnaire to capture school performance. } \\
\text { Medical records: Disease-related information }\end{array}$ & $\begin{array}{l}\text { Interaction sex } \times \text { age on peer relationships; } \\
\text { peer relationships of adolescent boys with } \\
\text { SCD negatively impacted but not girls. Pain } \\
\text { frequency significantly predicted school } \\
\text { performance; no comment on peer } \\
\text { relationships }\end{array}$ \\
\hline $\begin{array}{l}\text { Hunfeld et al, } 2001 \text { (33), } \\
\text { Netherlands, correlation } \\
\text { study }\end{array}$ & $\begin{array}{l}\mathrm{n}=128 \text { chronic pain patients } \\
\text { enrolled ( } 111 \text { included in } \\
\text { analysis because } 17 \text { had } \\
\text { missing data); no controls } \\
\text { 12-18 years } \\
95 \text { girls }\end{array}$ & $\begin{array}{l}\text { Parent: Impact on Family Scale. Adolescents: } \\
\text { Demographics, pain list, Quality of Life Pain in } \\
\text { Youth, 3-week daily pain diary }\end{array}$ & $\begin{array}{l}\text { More pain had a small negative impact on } \\
\text { social functioning. Quality of life social } \\
\text { functioning subscale included more than just } \\
\text { peer relationships }\end{array}$ \\
\hline $\begin{array}{l}\text { Langeveld et al, } 1997 \text { (25), } \\
\text { Norway, correlation study }\end{array}$ & $\begin{array}{l}\mathrm{n}=64 \text { HA patients (chronic } \\
\text { daily or migraine); no } \\
\text { controls } \\
12-18 \text { years } \\
42 \text { girls }\end{array}$ & $\begin{array}{l}\text { Adolescents: HA and migraine diary over } 4 \text { weeks, } \\
\text { QLH-Y }\end{array}$ & $\begin{array}{l}\text { No relationship between HA severity and } \\
\text { social interaction with peers across 4-week } \\
\text { study period }\end{array}$ \\
\hline $\begin{array}{l}\text { Merlijn et al, } 2003 \text { (35), } \\
\text { Netherlands, case-control } \\
\text { correlation study }\end{array}$ & $\begin{array}{l}n=548 \text {; chronic pain, } n=330 ; \\
\text { matched pain-free controls, } \\
n=218 \\
\text { 12-18 years } \\
\text { Chronic pain group, } 58 \text { boys; } \\
\text { pain-free group, } 32 \text { boys }\end{array}$ & $\begin{array}{l}\text { Parent: IBES - Parent, DPQ, Pain Coping Inventory. } \\
\text { Adolescent: Pain questionnaire, DPQ, } \\
\text { Achievement Motivation Test, social acceptance by } \\
\text { others subscale of the school questionnaire, } \\
\text { IBES - Child, PCQ, Quality of Life Questionnaire } \\
\text { for Adolescents with Chronic Pain }\end{array}$ & $\begin{array}{l}\text { Chronic pain participants have poorer quality } \\
\text { of life in all domains and } \downarrow \text { social } \\
\text { acceptance by others. Chronic pain group } \\
\text { perceived } \uparrow \text { reward from peers when pain- } \\
\text { free, compared with reward from parents. } \\
\text { Girls: Odds of having chronic pain } \downarrow \text { as } \\
\text { reward from peers in pain situations } \uparrow\end{array}$ \\
\hline $\begin{array}{l}\text { Powers et al, } 2004 \text { (26), } \\
\text { USA, comparison study; } \\
\text { normative data on the } \\
\text { PedsQL } 4.0\end{array}$ & $\begin{array}{l}\mathrm{n}=686 \text { migraine HA patients } \\
\text { 2-18 years }(2-4 \text { years, } \mathrm{n}=21 \text {; } \\
5-7 \text { years, } \mathrm{n}=86 ; 8-12 \text { years, } \\
\mathrm{n}=298 ; 13-18 \text { years, } \mathrm{n}=281 \text { ) } \\
391 \text { girls (ratio near } 1: 1 \text { in } \\
\text { each age group except } \\
\text { 13-18 years, with } 73 \% \text { girls) }\end{array}$ & $\begin{array}{l}\text { Parent: HA centre intake questionnaire (pain } \\
\text { intensity, frequency, location, PedsQL } 4.0- \\
\text { Parent Form. Child/Adolescent (5-18 years) } \\
\text { PedsQL } 4.0 \text { - Young Child/Child/Adolescent Form, } \\
\text { self-report of pain, location and frequency. } \\
\text { Physician: History and physical to diagnosis } \\
\text { migraine HA }\end{array}$ & $\begin{array}{l}\text { All age ranges of children and adolescents } \\
\text { with migraine have } \downarrow \text { quality of life scores } \\
\text { versus normative data, including social } \\
\text { functioning subscale. Young children scored } \\
\downarrow \text { on social functioning subscale versus } \\
\text { child or adolescent groups. Adolescents } \\
\text { scored } \downarrow \text { on school functioning subscale } \\
\text { versus young child and child groups }\end{array}$ \\
\hline
\end{tabular}

Continued on next page

In studies with a primary focus on quality of life, the aim was to explore the quality of life for children and adolescents with chronic pain. Age data presented as a range in years. CBCL Child Behavior Checklist; CHAQ Childhood Health Assessment Questionnaire; DPQ Dutch Personality Questionnaire; HA Headache; IBES IIIness Behavior Encouragement Scale; JPA Juvenile polyarticular arthritis; PCQ Pain Coping Questionnaire; PedsQL Pediatric Quality of Life Inventory; PPCI Waldron/Varni Pediatric Pain Coping Inventory; QLH-Y Quality of Life Headache in Youth; SCD Sickle cell disease 
TABLE 2 - CONTINUED

Studies with a primary focus on quality of life

\begin{tabular}{|c|c|c|}
\hline $\begin{array}{l}\text { Author, year (reference), } \\
\text { country, study type }\end{array}$ & Sample, age, sex & Measures \\
\hline $\begin{array}{l}\text { Sawyer et al, } 2004 \text { (29), } \\
\text { Australia, correlation study }\end{array}$ & $\begin{array}{l}n=59 \text { juvenile idiopathic } \\
\text { arthritis patients } \\
\text { 8-18 years } \\
40.7 \% \text { boys }\end{array}$ & $\begin{array}{l}\text { Parent: CHAQ, PPCI. Child: PedsQL 4.0, } \\
\text { PedsQL } 3.0 \text { (arthritis module), Varni/Thompson } \\
\text { Pediatric Pain Questionnaire, PPCI }\end{array}$ \\
\hline $\begin{array}{l}\text { Schanberg et al, } 2003(30) \text {, } \\
\text { USA, correlation study }\end{array}$ & $\begin{array}{l}n=41 \text { JPA patients } \\
8-18 \text { years } \\
59 \% \text { girls }\end{array}$ & $\begin{array}{l}\text { Parent: CHAQ - Parent Report. Child: Daily diaries } \\
\text { over } 2 \text { weeks (pain, pain location, stiffness, } \\
\text { fatigue, reduction of social and school activities), } \\
\text { CHAQ - Child Report, Child Depression Inventory } \\
\text { Revised Children's Manifest Anxiety Scale. } \\
\text { Physician/researcher: Baseline disease severity }\end{array}$ \\
\hline $\begin{array}{l}\text { Schanberg et al, } 2005 \text { (31), } \\
\text { USA, correlation study }\end{array}$ & $\begin{array}{l}n=51 \text { JPA patients } \\
8-17 \text { years } \\
65 \% \text { female }\end{array}$ & $\begin{array}{l}\text { Child: Daily diary (pain intensity, location, stiffness } \\
\text { and fatigue), daily events inventory, Facial } \\
\text { Affective Scale, daily school and social activity } \\
\text { reduction, CHAQ - Child Report. Physician: } \\
\text { Disease severity }\end{array}$ \\
\hline $\begin{array}{l}\text { Strine et al, } 2006 \text { ( } 27), \text { USA, } \\
\text { cross-sectional study }\end{array}$ & $\begin{array}{l}\mathrm{n}=9264 \text { HA patients } \\
4-17 \text { years } \\
\text { Sex not specified }\end{array}$ & $\begin{array}{l}\text { Parent: Extended version of the Strengths and } \\
\text { Difficulties Questionnaire, demographic data }\end{array}$ \\
\hline
\end{tabular}

Findings

Children report better quality of life scores

versus parents. Children and parents

reported $\downarrow$ social functioning problems

versus other domains. Child reports:

Significant negative relationship between

pain and PedsQL (including social

functioning subscale)

$66 \%$ of children $\downarrow$ social activities for at least 1 day during study period. Children $\downarrow$ social activities on $20 \%$ of their pain days. $12 \%$

$\downarrow$ social activities on $>40 \%$ of their pain days. 33\% did not $\downarrow$ their social activities on pain days

Pain, stress, mood, fatigue and stiffness influenced reductions in social activities. Social activities reduced versus school activities

42.1\% of parents of children with HAs reported some degree of difficulty with emotions, concentration, behaviour or getting along with peers. Children with HAs are 3.3 times more likely to face difficulties in friendships, 2.0 times more likely to play alone, 2.6 times more likely to be bullied and 1.3 times as likely to relate better to adults, versus normative data

Talarska and ZgorzalewiczStachowiak, 2007 (28),

Poland, correlation study

$\mathrm{n}=117$ HA patients

8-18 years ( $<12$ years, $\mathrm{n}=21$;

12-15 years, $n=39$;

$>15$ years, $n=57$ )

69 girls

Tsao et al, 2007 (34), USA, correlation study $\mathrm{n}=87$ chronic pain patients

10-18 years

62 girls
Parent: Demographic questionnaire, PedsQL 4.0. Child: PedsQL 4.0

Physical and social functioning negatively impacted by frequent and lasting $\mathrm{HA}$
Parent: Study demographic questionnaire. Child: Childhood Anxiety Sensitivity Index, Child Health Questionnaire - Child Form 87
Anxiety sensitivity was not associated with physical functioning or limitations in school work/activities with friends due to physical problems. Anxiety sensitivity associated with poorer social functioning (greater limitations in family activities and increased likelihood of social/academic limitations due to emotional problems among children with chronic pain). Pain-related characteristics (intensity, location, multiple pain diagnosis) did not account for significant incremental variance in quality of life

In studies with a primary focus on quality of life, the aim was to explore the quality of life for children and adolescents with chronic pain. Age data presented as a range in years. CBCL Child Behavior Checklist; CHAQ Childhood Health Assessment Questionnaire; DPQ Dutch Personality Questionnaire; HA Headache; IBES IIIness Behavior Encouragement Scale; JPA Juvenile polyarticular arthritis; PCQ Pain Coping Questionnaire; PedsQL Pediatric Quality of Life Inventory; PPCI Waldron/Varni Pediatric Pain Coping Inventory; QLH-Y Quality of Life Headache in Youth; SCD Sickle cell disease

\section{Primary focus: Mental health factors}

Nine studies in the present review focused on examining associations between pain and mental health factors such as internalizing or externalizing problems (Table 3). Similar to studies in the previous categories, pain types included headache, abdominal pain, arthritic type pain, SCD and nonspecific chronic pain. Similar to quality of life studies, data on peer relationships were generally obtained through social subscales on broad measures of social behaviour, as opposed to measures designed to specifically assess peer relationships. Only one group (38) created a questionnaire specifically for use in the study, based on the fact that standard behavioural and psychological inventories focused on psychopathology and did not adequately assess illness adjustment for urban African-American participants. The remainder of the studies used a wide range of existing measures.

Seven of the studies examining mental health factors, peer relationship difficulties, and chronic pain in children and adolescents indicate that those with chronic pain have increased peer relationship difficulty rates. Specifically, increased peer 
TABLE 3

Studies with a primary focus on mental health factors

\begin{tabular}{|c|c|}
\hline \multicolumn{2}{|l|}{ Author, year (reference) } \\
\hline country, study type & Sample, age, sex \\
\hline \multirow[t]{3}{*}{$\begin{array}{l}\text { Anttila et al, } 2004 \text { (40), } \\
\text { Finland, case-control } \\
\text { correlation study }\end{array}$} & $\begin{array}{l}n=183 \text {; tension-type } H A, n=65 \text {; } \\
\text { migraine } H A, n=59 ; \text { HA free, } \\
n=59\end{array}$ \\
\hline & 12.6 years \\
\hline & $\begin{array}{l}\text { Tension-type HA, n=21 girls; } \\
\text { migraine, } n=32 \text { girls; HA free, } \\
n=37 \text { girls }\end{array}$ \\
\hline \multirow{3}{*}{$\begin{array}{l}\text { Barbarin et al, } 1994 \\
\text { (38), USA, correlation } \\
\text { study }\end{array}$} & $\mathrm{n}=327$ SCD patients; no controls \\
\hline & 4-17 years \\
\hline & 145 females \\
\hline \multirow{3}{*}{$\begin{array}{l}\text { Campo et al, } 2004 \text { (42), } \\
\text { USA, case-control } \\
\text { study }\end{array}$} & $\mathrm{n}=42$ RAP patients \\
\hline & 8-15 years \\
\hline & $\begin{array}{l}18 \text { boys with RAP; controls } n=38 \text {, } \\
n=16 \text { boys }\end{array}$ \\
\hline
\end{tabular}

Measures

Parent: CBCL, McMaster Family Assessment

Device, child and family demographic variables (locally developed). Child: Structured HA interview, CDI
Findings

Children with migraines scored worse on the CBCL social problems subscale than the other 2 groups but there were no group differences on the CBCL social competence subscale
Parent: Custom survey - social adjustment problems (ie, shy, lonely, issues getting along with friends or lacking a close friend). Pain: Frequency of ischemic pain attacks

Parent: CBCL, Pediatric Symptom Checklist-17, SCARED, Junior Temperament and Character Inventory, Columbia Impairment Scale. Child: CDI, FDI - Child Form. Health professional: K-SADS-PL, Children's Global Assessment Scale

Parent: CBCL. Child: CDI, Piers-Harris Children's Self-Concept Scale
Shyness, loneliness and lack of a close friend were the social adjustment issues most frequently reported by parents

Statistically significant difference in social phobia for RAP group versus controls on parent SCARED. No differences on the child SCARED between groups. Statistically significant difference on the CBCL social competence and social problems subscales between groups. K-SADS-PL: $21.4 \%$ of participants with RAP had social phobia

Gold et al, 2000 (41), $\mathrm{n}=62 ;$ IBD, $\mathrm{n}=36$; FGI, $\mathrm{n}=26$ 8-18 years $63 \%$ boys study Significant difference between those with n=2588 (cross-sectional nationally Child: Statistics Sweden home-based interview representative sample)

10-18 years

1296 boys

Kaminsky et al, 2006 (46), Canada, correlation study $\mathrm{n}=50$ RAP patients; no controls 8-17 years 41 girls with parents and children plus a questionnaire bullying

Parent: FDI, Brief Symptom Inventory, CBCL. Child: Abdominal Pain Index, FDI, Pain
Karwautz et al, 1999 (43), Austria, casecontrol study $\mathrm{n}=341$; migraines, $\mathrm{n}=151$; tension-type HA, $n=94$; HA free, $\mathrm{n}=96$

4-19 years

175 boys ( $1: 1$ ratio with girls; both evenly spaced across HA groups)

Mullick et al, 2005 (44), $n=80 ; J I A, n=40$; matched peers, Bangladesh, case- $\quad \mathrm{n}=40$ control comparison 10-18 years study

24 boys with JIA

Sandstrom and $n=36$ juvenile rheumatic disease Schanberg, 2004 (45), patients

USA, correlation study 7-16 years 27 girls booklet. Questions on pain, school stressors and Response Inventory for Children, Social Support Scale for Children, Pain Coping Questionnaire, Children's Health Locus of Control Scale, CDI, State-Trait Anxiety Inventory for Children

Mothers: Study-specific questionnaire on psychosocial factors. Clinician interview: HA diagnosis (including pain characteristics of the HA) with parent and child

Participants with tension-type HA reported to have $\downarrow$ friends, more likely to have divorced parents compared with participants with migraine or HA-free controls
Social support by classmates and teachers associated with $\downarrow$ depressive symptoms in children with RAP (explained $7 \%$ of the variance) constipation and RAP (both from the FGI group) (constipation scored as being less socially mpetent)

Children with $\uparrow$ victimization rates, perceived lack of teacher support and schoolwork pressures reported more abdominal pain and HAs
Parent: Strengths and Difficulties Questionnaire, demographic data. Researcher: Semistructured case assessment sheet

Child: Pain (visual analogue scale), Childhood Health Assessment Questionnaire. Teacher: Teacher Checklist of Social Behavior, CDI. Rheumatologist: Disease severity measure

\section{$52.5 \%$ of JIA participants reported peer relationship difficulties. $70.43 \%(n=10)$ with both JIA and psychiatric disorders reported peer relationship difficulties. $42.3 \%(n=11)$ with JIA only reported peer relationship difficulties Social rejection by peers moderated the relationship between pain severity and depressive symptoms in that rejection exacerbated the positive impact of pain on depressive symptoms}

In studies with a primary focus on mental health factors, the aim was to explore the association between mental health factors (depression, anxiety and psychosomatic complaints) and chronic pain. Age data presented as a range in years. CBCL Child Behavior Checklist; CDI Child Depression Index; FDI Functional Disability Inventory; FGI Functional gastrointestinal condition; HA Headache; IBD Inflammatory bowel disease; JIA Juvenile idiopathic arthritis; K-SADS-PL Schedule for Affective Disorders and Schizophrenia for School Age Children, Present and Lifetime Version; RAP Recurrent abdominal pain; SCARED Screen for Child AnxietyRelated Emotional Disorders; SCD Sickle cell disease

victimization rates $(38,39)$, poorer scores on the Child Behavior Checklist (CBCL) social problem subscale (40) and social competence subscale (41), a greater incidence of social phobia than in healthy controls (42), and fewer friends (43). However, as noted by Mullick et al (44) in 2005, although $70 \%$ of children with both a comorbid mental health condition and JIA experienced negative peer relationships, a significant number of children and adolescents without a comorbid mental health 
condition ( $42 \%$ of those with JIA only) also experienced negative peer relationships, suggesting that mental health difficulties may not be the primary determinant of peer difficulties in children and adolescents with chronic pain. It is important to note that none of the abovementioned studies examined the specific cause and effect relation between chronic pain, mental health concerns and peer relationships.

Two studies in this category suggest that acceptance by peers is important as a moderator in the relationship between peer difficulties, mental health factors and chronic pain. In 2004, Sandstrom and Schanberg (45) examined the associations among severity of juvenile rheumatoid arthritis, social competence and depressive symptomatology, and found that social rejection by peers moderated the relationship between pain severity and depressive symptoms for children and adolescents with juvenile rheumatoid arthritis. Social rejection exacerbated the impact of pain on depressive symptoms for these children and adolescents, whereas social support from classmates and teachers was associated with fewer depressive symptoms in children with RAP (46). More research is needed to examine the protective role of peers for children and adolescents with chronic pain.

Overall, mental health factors and chronic pain were associated with increased rates of peer relationship difficulties. However, mental health factors alone did not account for all the differences in social or peer relationships, meaning that the presence of chronic pain may have a unique impact. Additionally, peers may play a protective mental health role for children and adolescents with chronic pain.

\section{Primary focus: Other}

Nine studies were categorized as 'other' due to the fact that their primary focus did not fit into one of the three categories discussed above (Table 4). The primary purpose of these studies ranged from population studies examining physical and behavioural correlates associated with headaches (47) to mothers' attributions of the causes and remedies for their child or adolescent's abdominal pain (48). Similar to most of the other studies discussed in the present review, peer relationships of children and adolescents with chronic pain were assessed using subscale items on more global measures of behaviour and/or psychosocial functioning. Findings with respect to peer relationships in this group of studies were mixed, but generally indicated that there was some negative impact on peer relationships for children and adolescents with chronic pain.

The two studies that employed population-based samples found that victimization and school stress were significantly positively correlated with nonmigraine headaches in girls, whereas migraine headaches in boys were significantly positively correlated with difficulties in getting along with peers (47); and that students with more frequent pain had fewer friends than those with infrequent pain (49). Although Larsson and Sund (49) reported in 2007 that the number of friends did not change over the year of the study, they did not provide information regarding actual quantities of friends; therefore, it is unclear how many fewer friends these children have in relation to healthy children.

The two studies that used school- or clinic-based populations indicated that the frequency of meeting friends was negatively affected for children experiencing pain. In their 2005 school-based study, Roth-Isigkeit et al (50) found that children and adolescents experiencing abdominal pain and headache reported almost twice the amount of pain-related interference with meeting friends compared with those experiencing back or limb pain. In clinical samples of children and adolescents with chronic pain, those with headache-only pain reported the highest modifications to contact with friends (eg, having to stop, reduce or adjust contact with peers) compared with those with musculoskeletal (MSK) pain and abdominal pain (51). Moreover, Konijnenberg et al (51) found in 2005 that participants with unexplained chronic pain (regardless of pain location) had considerably lower levels of physical and role/social functioning than previously published school samples that included subgroups with other chronic diseases, suggesting that chronic pain interferes with peer relationships in a way that other chronic illnesses without pain do not.

Two of the nine studies in this category focused on adolescents with idiopathic MSK pain and found differing results. In 2004, Guite et al (52) found no differences in the social acceptance and close friendship subscales of the Self-Perception Profile for Adolescents between a clinical sample of adolescents with idiopathic MSK and normative adolescent samples. Conversely, in 1997, Flato et al (53) found that participants with idiopathic MSK pain who were still experiencing pain at 10-year follow-up had poorer psychosocial scores, based on the Children's Global Assessment Scale or the Global Assessment Scale, than participants with juvenile chronic arthritis. Although peer relationships are a factor in these scales, other factors, such as functioning at work or school and family functioning, are also included (53), making it difficult to determine the degree to which each of these factors impacted the psychosocial well-being of the participants.

The last three studies within this category investigated social functioning in children and adolescents with recurrent unexplained abdominal pain. In a 1999 study examining maternal attributions for the causes of and remedies for their child or adolescent's abdominal pain, Claar and Walker (48) found that although mothers believed that peer relationship difficulties contributed to their child's abdominal pain, they believed that other nonsocial factors, such as too much acid in the stomach or improper eating, contributed more. Additionally, mothers whose children had unexplained pain believed that problems with peers at school contributed less to their child's pain $(8.2 \%)$ than mothers whose children had organic abdominal pain (12.7\%). The other two studies identified the benefits of positive peer relationships for children and adolescents with RAP. Friend support was associated with improved selfperceived social competence for children with RAP (54), and greater social support from peers was noted to buffer the effects of negative family events on the health of these children and adolescents (55). These three studies suggest that peer relationships can be a source of both stress and support for children with abdominal pain.

In summary, all but one study in this category found some form of impact on social functioning and/or peer relationships for children and adolescents with chronic pain. Pain resulted in decreased opportunities to engage with friends, having fewer friends and increased rates of peer victimization. However, supportive peers may help buffer some of these negative effects. 


\section{TABLE 4}

Studies with a primary focus categorized as 'other'

\begin{tabular}{|c|c|c|c|}
\hline $\begin{array}{l}\text { Author, year (reference), } \\
\text { country, study type }\end{array}$ & Sample, age, sex & Measures & Findings \\
\hline $\begin{array}{l}\text { Claar and Walker, } 1999 \\
\text { (48), USA, case } \\
\text { comparison study }\end{array}$ & $\begin{array}{l}\text { n=153; organic disease, } n=55 ; \\
\text { unexplained abdominal pain, } \\
\text { n=98; no controls } \\
6-18 \text { years } \\
\text { Organic disease, } 52.7 \% \text { girls; } \\
\text { unexplained abdominal pain, } \\
61.2 \% \text { girls }\end{array}$ & $\begin{array}{l}\text { Parent: Inventory of Causes for } \\
\text { Abdominal Pain, Inventory of } \\
\text { Remedies for Abdominal Pain }\end{array}$ & $\begin{array}{l}\text { Most mothers attributed causes and remedies of both } \\
\text { types of abdominal pain to factors other than peer } \\
\text { relationships. } 8.2 \% \text { of mothers in unexplained pain } \\
\text { group indicated problems with peers at school } \\
\text { contributed to their child's pain. } 12.7 \% \text { of the mothers } \\
\text { in organic abdominal pain group indicated difficulties } \\
\text { with peers as a contributing factor to their child's pain }\end{array}$ \\
\hline $\begin{array}{l}\text { Flato et al, } 1997 \text { (53), } \\
\text { Norway, correlation } \\
\text { study }\end{array}$ & $\begin{array}{l}\text { n=109 MSK pain patients; } \\
\text { idiopathic, } n=37 ; \text { JCA, } n=72 \\
\leq 16 \text { years on initial assessment, } \\
\text { follow-up } 9 \text { years later }\end{array}$ & $\begin{array}{l}\text { Rheumatologist: Clinical and laboratory } \\
\text { data, and radiographic examinations. } \\
\text { Adolescent: Childhood Health } \\
\text { Assessment Questionnaire, Health }\end{array}$ & $\begin{array}{l}\text { Idiopathic MSK pain group still experiencing pain at } \\
\text { follow-up had worse psychosocial scores than JCA } \\
\text { group. Psychosocial issues included school, friends } \\
\text { and family functioning }\end{array}$ \\
\hline
\end{tabular}

Assessment Questionnaire, authoradministered semistructured psychiatric interview

Parents: Family demographics, onset and duration of adolescents' pain problem, school absences, Hollingshead Four-Factor Index of Social Status. Adolescents: Pain VAS, FDI, SPPA

$\begin{array}{cl}\text { Guite et al, 2004 (52), } & \mathrm{n}=115 \text { MSK pain patients } \\ \text { USA, correlation study } & \begin{array}{l}13-18 \text { years } \\ 96 \text { girls }\end{array}\end{array}$

Konijnenberg et al, 2005 (51), Netherlands, correlation study

\section{$\mathrm{n}=149 \mathrm{HA}, \mathrm{MSK}$ pain and abdominal pain patients 8-18 years \\ Child: CSI, Child Health \\ Questionnaire - Child Form 87, Pediatric Pain Questionnaire} $73 \%$ girls
SPPA subscales related to peers and friend relationships minimally correlated with pain or functional disability. Global self worth contributed minimally to disability variance

$40 \%$ of participants had $\downarrow$ or adjusted contact with friends. Two participants reported complete isolation from friends. $14 \%$ of children with school absences missed 3 or more consecutive months. Suffering from HA resulted in $\uparrow$ interference with role/social functioning compared with MSK or abdominal pain; social impairment evolved after sport and school activities were affected. Children with unexplained chronic pain had considerably $\downarrow$ levels of physical and role/social functioning compared with a previously reported school sample including subgroups with chronic diseases

Students with $\uparrow$ frequent pain (regardless of number of sites) had fewer friends than those with infrequent pain at both time 1 and one year later at time 2

characteristics, social factors (numbe of friends $0-1$ or 2 or more, divorced parents, school absence and reduced leisure time activities), pain symptoms, daily hassles, Mood and Feelings Questionnaire (youth self-report)

Metsähonkala et al, 1998 n=3580; migraine HA, n=95 (2.7\%); Parents: Questionnaire to capture (47), Finland, population- nonmigraine HA, n=977 (27.3\%); based, nonselective, HA free, $\mathrm{n}=2246(62.7 \%)$ prospective cohort study 8-9 years general health status, school attendance and HA information
Peer relationship difficulties strongly associated with migraine in boys. Bullying and school stress significantly associated with nonmigraine HA in girls
Roth-Isigkeit et al, 2005 (50), Germany, schoolbased cross-sectional study
Girls - migraine $43.2 \%$,

nonmigraine $49.7 \%$

$\mathrm{n}=749$ multiple pain types

4-18 years

$52.5 \%$ girls

\author{
Older children: Luebeck Pain-Screening \\ Questionnaire - version 2, VAS for \\ pain, 'smiley' faces scale. Adolescent: \\ Luebeck Pain-Screening \\ Questionnaire - version 3, VAS for \\ pain, 'smiley' faces scale. Parent: \\ Luebeck Pain-Screening \\ Questionnaire - version 1 (parent \\ version for young children), VAS, \\ 'smiley' faces scale
}

$83 \%$ had pain within the previous 3 months, with $54.4 \%$ having frequent pain over the previous 3 months. $46.7 \%$ of the total participants did not meet with friends due to pain at least once $(32.9 \%$ sometimes, $13.8 \%$ often missed out meeting friends due to pain). Those with HA and abdominal pain missed meeting friends more than those with limb or back pain. Girls between 13-15 years of age had $\uparrow$ pain-related interference with friends; no sex differences in other age groups (4-9 years; 10-12 years; 16-18 years)

Continued on next page

In studies with a primary focus of 'other', the aim of the studies included association of risk factors with pain, mother's attributions of their child's pain, etc. CSI Children's Somatization Inventory; FDI Functional Disability Inventory; HA Headache; HRI Health Resources Inventory; JCA Juvenile chronic arthritis; MSK Musculoskeletal; RAP Recurrent abdominal pain; SPPA Self-Perception Profile for Adolescents; SPPC Self-Perception Profile for Children; VAS Visual analogue scale 
TABLE 4 - CONTINUED

Studies with a primary focus categorized as 'other'

\begin{tabular}{|c|c|c|c|}
\hline $\begin{array}{l}\text { Author, year (reference), } \\
\text { country, study type }\end{array}$ & Sample, age, sex & Measures & Findings \\
\hline $\begin{array}{l}\text { Walker et al, } 2002 \text { (54), } \\
\text { USA, correlation study }\end{array}$ & $\begin{array}{l}n=151 \text { RAP patients } \\
8-18 \text { years } \\
57 \% \text { girls }\end{array}$ & $\begin{array}{l}\text { Child: Social consequences of pain, } \\
\text { CSI, SPPC, Multidimensional Scale of } \\
\text { Perceived Social Support }\end{array}$ & $\begin{array}{l}\text { Friend support had a significant, moderate, positive } \\
\text { correlation with self-perceived academic and social } \\
\text { competence for children with RAP }\end{array}$ \\
\hline $\begin{array}{l}\text { Walker et al, } 1994(55) \text {, } \\
\text { USA, longitudinal } \\
\text { correlation study }\end{array}$ & $\begin{array}{l}\text { n=197 chronic abdominal pain } \\
\text { patients; organic pain, } n=68 ; \\
\text { specific pain syndrome, } n=26 ; \\
\text { nonspecific pain syndrome, } \\
n=103 \\
6-18 \text { years } \\
59 \% \text { girls }\end{array}$ & $\begin{array}{l}\text { Parent: Family Inventory of Life Events, } \\
\text { HRI, Symptoms Checklist 90. Child: } \\
\text { CSI, SPPC. Teacher: HRI }\end{array}$ & $\begin{array}{l}\text { Social competence had a significant, moderate, } \\
\text { negative correlation with child symptoms at time } 1 \\
\text { and time } 2 \text {. Interaction between negative family life } \\
\text { events and social competence (social skills and peer } \\
\text { acceptance) on CSI scores. High social competence } \\
\text { (peers) appears to buffer negative effects of family } \\
\text { life events for children with chronic abdominal pain }\end{array}$ \\
\hline
\end{tabular}

In studies with a primary focus of 'other', the aim of the studies included association of risk factors with pain, mother's attributions of their child's pain, etc. CSI Children's Somatization Inventory; FDI Functional Disability Inventory; HA Headache; HRI Health Resources Inventory; JCA Juvenile chronic arthritis; MSK Musculoskeletal; RAP Recurrent abdominal pain; SPPA Self-Perception Profile for Adolescents; SPPC Self-Perception Profile for Children; VAS Visual analogue scale

\section{DISCUSSION}

Despite two decades of research examining chronic pain in children and adolescents, very little is known about the peer relationships of this group of children. As part of the current review, only nine studies were specifically designed to assess peer relationships in this population. Based on the available research, it appears that peer relationships may be problematic for some children and adolescents with chronic pain; however, findings are not uniform across studies or pain conditions, making it difficult to draw broad conclusions regarding the exact nature of peer relationships in this population. For example, in some studies, children with migraines were found to have more difficulties with peer relationships, but other studies found that tension headaches appeared to be more predictive of peer difficulties. A similar pattern was observed in studies of children and adolescents with abdominal pain, in that some studies reported no differences (or unexpected differences) between organic and nonorganic abdominal pain, whereas other studies indicated that children and adolescents with nonorganic abdominal pain were subjected to increased rates of peer victimization.

Overall, children and adolescents with chronic pain were found to participate in fewer peer activities, have fewer friends, and were perceived as being more isolated than their healthy peers. Findings from two studies $(17,18)$ indicated that children and adolescents with chronic pain were perceived as less likeable by their peers, but this pattern was not observed among school-age children when assessing the likeability of a hypothetical peer in a series of vignettes (22) or a more recent study (16) of children and adolescents with SCD. This being said, it remains unclear whether participating in fewer activities or having fewer friends translates into poor friendship quality, nor is it clear whether decreased participation or fewer friends negatively impacts a child or adolescent's pain. Pain limits the individual's engagement in activities; however, research to date has not identified whether pain becomes worse when the individual does not engage in these activities.

Despite pain being a major symptom in all of the health conditions described above, it is difficult to draw conclusions regarding the impact of pain intensity, frequency and duration on peer relationships because most studies did not examine these pain factors and/or used various pain measures. For example, among the studies in the peer relationship category, few pain-specific factors were assessed. In a study of adolescents with JIA (15), 47\% of the participants had moderate to severe disease, as well as active disease, but ratings of pain variables were not obtained. Additionally, with respect to adolescents with JFS (18), severe pain in at least five of 11 tender points constituted part of the study inclusion criteria; however, no ratings of pain intensity or frequency were provided. In 2008, Vannatta et al (19) included reports of pain frequency and intensity, but did not include these ratings in their study because they did not correlate significantly with scores on the peer relationship measures. In their original 1996 study of children and adolescents with SCD, Noll et al (17) collected ratings of pain frequency, but not intensity, as part of a general measure of disease severity. Given that disease severity was not found to be significantly associated with scores on friendship measures, the authors chose not to include pain or disease severity when replicating this study. As part of their 2007 study of victimization of children and adolescents with RAP, Greco et al (14) asked participants to complete the Abdominal Pain Index, a tool that measures frequency, duration and intensity of abdominal pain; however, no discussion of these variables was provided. Finally, in 2004, Wagner et al (21) included pain intensity ratings (measured on a $100 \mathrm{~mm}$ visual analogue scale) as a single variable, and were therefore able to investigate the association between pain ratings and scores on social measures. Interestingly, their study found that pain intensity was a contributing factor to how participants viewed peer interactions. Studies included in the three other categories had similar deficiencies in reporting pain variables, which complicates our understanding of pain's impact on peer relationships in youth challenged by chronic pain.

In addition to the variety of methods and primary focuses of the studies included in the present review, direct comparison between studies is complicated by the range of pain types studied, the age range within studies and the variety of measures used to assess social functioning. Studies focusing specifically on peer relationships made use of self-report measures and some included peer-report measures, which was not the case in the other categories. All but one of the studies included in the current review were conducted in western countries and, therefore, understanding cultural differences in peer relationships 
for children and adolescents with chronic pain requires further study.

Although our intent was to extract child factors in addition to pain that may impact peer relationships, this was difficult because many of these factors were not assessed. In particular, the age range of participants is noteworthy because age ranged from four to 19 years, with most studies including both children and adolescents. The few adolescent-only studies included both early and late adolescent participants. Including participants of such diverse ages in a single study makes it difficult to detect developmental differences in peer relationships. The qualities one needs and desires within friendships develop as the individual's understanding of the world increases and his or her social needs expand (1).

Participants experienced five broad types of pain in the 42 studies reviewed: headache, abdominal pain, arthritic types of pain, SCD pain and chronic pain of unknown etiology. These types of pain represent both recurrent and continuous pain. None of the studies captured the recurrent or continuous nature of the participants' pain, leaving the underlying condition as the only way to determine whether the pain was recurrent or continuous. This being said, no one type of recurrent pain was found to negatively impact peer relationships more than another. Studies including chronic pain of unknown etiology did not differentiate recurrent from continuous pain within the participant group, meaning that it is unclear whether certain types of pain conditions affect peer relationships more than others. In 2007, Kashikar-Zuck et al (18) were the only group to include only participants whose pain could be characterized as continuous; results indicated that adolescents with JFS were perceived more negatively by their peers.

In trying to understand the causes of differences between adolescents with JFS and healthy peers, Kashikar-Zuck et al (18) suggested in 2007 that the prevalence of comorbid mental health conditions, such as increased anxiety, social withdrawal and depressive symptoms, may be a contributing factor in their findings. However, the cause and effect relation between JFS and mental health difficulties was not examined in their study, making it difficult to draw conclusions regarding the nature of this association. Additionally, the other studies $(16,17,19)$ employing the same classroom measures did not suggest comorbid mental health conditions as contributing to the differences they found in peer relationships. However, the summary of findings within the primary focus of mental health difficulties suggest that comorbid mental health difficulties may add to peer relationship difficulties for children and adolescents with chronic pain. Therefore, more research is needed to examine the relationship between comorbid mental health difficulties, peer relationships and chronic pain.

In addition to comorbid mental health conditions as potential contributing factors to differences in peer relationships between adolescents with JFS and healthy peers, in 2007, Kashikar-Zuck et al (18) questioned whether unknown etiology could influence the peer relationships and peer perceptions of children experiencing chronic pain. Although the etiology of JFS is not as clearly understood compared with the etiology of JIA, SCD or migraine, in 2000, Guite et al (22) offered preliminary support for the assertion that underlying pain etiology may not be an important factor in determining likeability and peer acceptance of children and adolescents experiencing chronic pain. Certainly, more research is warranted to better understand the relation between perceived pain etiology and peer perceptions of youth with chronic pain. It is possible that younger children remain concrete in their understanding of the underlying causes of pain; therefore, the underlying etiology is not a factor in determining their acceptance of an individual with chronic pain. Alternatively, it is possible that ongoing contact with children and adolescents experiencing pain may negatively impact relationships with healthy peers.

Most studies included in the current review used standard behavioural measures with social subscales (eg, CBCL, Children's Somatization Inventory, Child Depression Inventory, Pediatric Quality of Life Inventory, Functional Disability Inventory) to assess peer relationships and social functioning, and parent reports were the most common source of information. In studies that included self-report, the individual child or adolescent did not necessarily complete the measures containing the social subscale. The CBCL was the most frequently used measure of social functioning and was included in nine of the studies; the social subscale of this measure includes items tapping family and sibling engagement in addition to peer engagement, making it difficult to determine which specific factors contribute to social problems or competencies.

Little is known about the impact of chronic pain on the quality of peer relationships. It appears that children and adolescents with chronic pain are subjected to higher rates of victimization than healthy children $(14,20,38)$, but population-based studies do not address the cause and effect nature of this association. That is, it is not clear whether the stress of victimization results in pain or whether children and adolescents with chronic pain are viewed as vulnerable and/or different, thus leading them to become targets for victimization $(39,47)$.

In children and adolescents who do not suffer from chronic pain, it has been suggested that a reciprocal friendship can buffer the negative effects of victimization, negative family environments and depression linked to loneliness (2-4). Three studies illustrated the power of positive friendships, in that they may improve pain and buffer negative family interactions (55) or peer effects (46) on a child's abdominal pain and improve self-perceived social competence (54). Several unanswered questions remain with respect to the nature of reciprocal friendships in youth with chronic pain, namely whether protective effects of reciprocal friendships exist for other pain types; the manner in which reciprocal friendships exert their protective effects; the number of reciprocal friendships needed to exert a protective effect on a child or adolescent who is more isolated from activities and school compared with healthy peers; and the impact of childhood chronic pain on adult peer relationships. Additionally, it is unclear whether children with chronic pain value different qualities in their peer relationships than healthy children.

Examination of qualitative research was beyond the scope of the current review. As noted above, some of the concerns raised by children and adolescents with chronic pain within such studies indicate that peer relationships can be challenging for this population. In addition to missing out on activities, children and adolescents voiced experiencing disbelief by some friends and nonfriend peers, and having friends that were only 
there on the good days. Lack of pain knowledge and understanding by peers was noted as a source of frustration $(7,9,56)$. Some children and adolescents described supportive, understanding friends $(7,56)$ who provided them with opportunities to engage in conversations and other activities that helped them to forget their pain condition (56) or distracted them during pain exacerbations (7). The measures used in the quantitative studies reviewed would not have adequately assessed many of the concerns or benefits of peer relationships raised by these adolescents.

\section{FUTURE DIRECTIONS}

Future research should focus on the development of specific measures to assess peer relationships in children and adolescents with chronic pain using ratings from a variety of sources (eg, parents, self, teachers and peers). This multidimensional approach to assessment is ideal because it is possible to assess the individual across multiple settings. Additionally, given the personal nature of friendships, it is possible that informants such as parents or teachers would lack some degree of insight into the quality and quantity of the child or adolescent's peer relationships. Additionally, more studies could make use of the pain diary method to examine interpersonal factors impacting pain.

Although five of the studies (15-19) included in the present review used classroom measures that included items related to likeability, reciprocal friendships and leadership skills, it is plausible that the friends of a given participant were in a different class or associated with a context other than school. With this is mind, it is important to assess relationships other than with classmates to gain a complete understanding of social functioning in children and adolescents with chronic pain. Many of these studies concentrated on the number of friendships, which may be indicative of an individual's popularity as opposed to true mutual friendships. More research specifically investigating the dyadic reciprocal friendships of children and adolescents with chronic pain is needed to understand whether these children experience differences compared with children and adolescents without pain. Victimization and chronic pain were found to be associated in studies from the four primary focus categories, but empirical research is needed to examine the relationship between pain and victimization rates. No longitudinal or developmental studies were retrieved as part of the literature search for the current review; therefore, it is difficult to determine whether living with chronic pain as a child or adolescent impacts adult peer relationships. It is also unclear how pain affects the development of relationships or social skills. As noted previously, most studies included a very wide range of ages; studies examining peer relationships in a more limited range of participants would perhaps provide insight that remains elusive in studies involving wide age ranges.

Finally, inconsistencies in reporting pain-related characteristics made it difficult to determine which components of

\section{REFERENCES}

1. Rubin KH, Chen X, Coplan R, Buskirk A, Wojslawowicz JC.

Peer relationships in childhood. In: Bornstein MH, Lamb ME, eds.

Developmental Science: An Advanced Textbook, 5th edn.

Mahwah, NJ: Erlbaum, 2005:469-512.

2. Gauze C, Bukowski WM, Aquan-Assee J, Sippola LK. Interactions

between family environment and friendships and associations with self-perceived well-being during early adolescence. Child Dev

1996;67:2201-16. pain were most problematic in social relations with peers. Future research would benefit from a standardized method of examining pain characteristics, thereby facilitating direct comparisons between children with chronic pain and healthy controls. A more direct examination of the relation between specific pain factors and peer relationships could potentially lead to more direct and streamlined interventions for children and adolescents challenged by chronic pain. A call for standardized pain assessment in research has been made in the area of clinical trials and is being addressed by the Pediatric Initiative on Methods, Measurement, and Pain Assessment in Clinical Trials (57). Although more research is needed to ascertain which pain characteristics are most appropriate to measure when examining peer relationship outcomes, it is important that key pain information, such as pain intensity, frequency and duration, be assessed and reported.

\section{CONCLUSION}

Despite acknowledging the importance of peer relationships in children and adolescents with chronic pain, little research exists that specifically and empirically examines the impact of chronic pain on peer relationships. Studies included in this descriptive systematic review suggest that children and adolescents with chronic pain may have fewer friends, are more isolated, and may be subjected to increased rates of victimization by peers compared with children and adolescents without pain. However, the range of study objectives and measures used makes it difficult to conclusively identify which pain factors contribute to negative or positive peer relationships, and how negative or positive peer relationships impact a child or adolescent's pain experience. More directed empirical research will ultimately lead to increased awareness of peer relationship challenges for children with chronic pain among patients, parents, clinicians and researchers, and will ensure positive outcomes for youth challenged by pain.

ACKNOWLEDGEMENTS: The present research was supported in part by a Development Funds for an Emerging Team grant ("Understanding chronic pain and pain-related disability in children") from the Canadian Institutes of Health Research (CIHR). PF is supported by a CIHR Doctoral Fellowship - Clinical Research Initiative and a President's Award from Dalhousie University (Halifax, Nova Scotia). SK is a CIHR Training Fellow in the Canadian Child Health Clinician Scientist Program (CCHCSP), in partnership with SickKids Foundation (Toronto, Ontario), Child \& Family Research Institute (Vancouver, British Columbia), Women \& Children's Health Research Institute (Edmonton, Alberta) and Manitoba Institute of Child Health (Winnipeg, Manitoba). JS is supported by a CIHR Post-Doctoral Fellowship, the CCHCSP and the Canadian Arthritis Network. PJM and CTC hold Canada Research Chairs.

3. Hodges EVE, Boivin M, Vitaro F, Bukowshi WM.

The power of friendship: Protection against an escalating cycle of peer victimization. Dev Psychol 1999;35:94-101.

4. Nangle DW, Erdley CA, Newman JE, Mason CA, Carpenter EA. Popularity, friendship quantity, and friendship quality: Interactive influences on children's loneliness and depression. J Clin Child Adolesc Psychol 2003;32:546-55. 
5. Smith J, Osborn M. Pain as an assault on the self: An interpretative phenomenological analysis of the psychological impact of chronic benign low back pain. Psychol Health 2007;22:517-34.

6. Snelling J. The effect of chronic pain on the family unit. J Adv Nurs 1994;19:543-51.

7. Forgeron P, McGrath PJ. Self-identified needs of adolescents with chronic pain. J Pain Manag 2008;1:163-72.

8. Carter B, Lambrenos K, Thursfield J. A pain workshop: An approach to eliciting the views of young people with chronic pain. J Clin Nurs 2002;11:753-62.

9. Sällfors C, Fasth A, Hallberg LR. Oscillating between hope and despair: A qualitative study. Child Care Health Dev 2002;28:495-505

10. Perquin CW, Hazebroek-Kampschreur AA, Hunfeld JA, et al. Pain in children and adolescents: A common experience. Pain 2000;87:51-8.

11. Stanford EA, Chambers CT, Biesanz JC, Chen E. The frequency, trajectories and predictors of adolescent recurrent pain: A population-based approach. Pain 2008;138:11.

12. Vickers AJ, Smith C. Incorporating data from dissertations in systematic reviews. Int J Technol Assess Health Care 2000;16:711-3.

13. Crowther MA, Cook DJ. Trials and tribulations of systematic reviews and meta-analyses. Hematol Am Soc Hematol Educ Program 2007:493-7.

14. Greco LA, Freeman KE, Dufton L. Overt and relational victimization among children with frequent abdominal pain: Links to social skills, academic functioning, and health service use. J Pediatr Psychol 2007;32:319-29.

15. Noll RB, Kozlowski K, Gerhardt C, Vannatta K, Taylor J, Passo M. Social, emotional and behavioral functioning of children with juvenile rheumatoid arthritis. Arthritis Rheum 2000;46:1387-96.

16. Noll RB, Reiter-Purtill J, Vannatta K, Gerhardt CA, Short A. Peer relationships and emotional well-being of children with sickle cell disease: A controlled replication. Child Neuropsych 2007;13:173-87.

17. Noll RB, Vannatta K, Koontz K, Kalinyak K. Peer relationships and emotional well-being of youngsters with sickle cell disease. Child Dev 1996;67:423-36.

18. Kashikar-Zuck S, Lynch A, Graham B, Swain N, Mullen SA. Social functioning and peer relationships of adolescents with juvenile fibromyalgia syndrome. Arthritis Rheum 2007;57:474-80.

19. Vannatta K, Getzoff EA, Gilman DK, et al. Friendships and social interactions of school-aged children with migraine. Cephalalgia 2008;28:734-43.

20. Natvig GK, Albrektsen G, Qvarnstrom U. Psychosomatic symptoms among victims of school bullying. J Health Psychol 2001;6:365-77.

21. Wagner JL, Connelly M, Brown RT, Taylor L, Rittle C, Wall-Cloues B. Predictors of social anxiety in children and adolescents with sickle cell disease. J Clin Psychol Med Settings 2004;11:243-52.

22. Guite JW, Walker LS, Smith CA, Garber J. Children's perceptions of peers with somatic symptoms: The impact of gender, stress, and illness. J Pediatr Psychol 2000;25:125-35.

23. Bandell-Hoekstra IE, Abu-Saad HH, Passchier J, Frederiks CMA, Feron FJM, Knipschild P. Coping and quality of life in relation to headache in Dutch schoolchildren. Eur J Pain 2002;6:315-21.

24. Brna PK, Gordon K, Dooley J. Canadian adolescents with migraine: Impaired health-related quality of life. J Child Neurol 2008;23:39-43.

25. Langeveld JH, Koot HM, Passchier J. Headache intensity and quality of life in adolescents. How are changes in headache intensity in adolescents related to changes in experienced quality of life. Headache 1997;37:37-42.

26. Powers SW, Patton SR, Hommel KA, Hershey AD. Quality of life in paediatric migraine: Characterization of age-related effects using PedsQL 4.0. Cephalalgia 2004;24:120-7.

27. Strine TW, Okoro CA, McGuire LC, Balluz LS. The associations among childhood headaches, emotional and behavioral difficulties, and health care use. Pediatrics 2006;117:1728-35.

28. Talarska D, Zgorzalewicz-Stachowiak M. The influence of selected factors on the quality of life of children with headaches. Adv Med Sci 2007;52(Suppl 1):123-5.
29. Sawyer MG, Whitham JN, Roberton DM, Taplin JE, Varni JW, Baghurst PA. The relationship between health-related quality of life, pain and coping strategies in juvenile idiopathic arthritis. Rheumatology 2004:43:325-30.

30. Schanberg LE, Anthony KK, Gil KM, Maurin EC. Daily pain and symptoms in children with polyarticular arthritis. Arthritis Rheum 2003;48:1390-7.

31. Schanberg LE, Gil KM, Anthony KK, Yow E, Rochon J. Pain, stiffness, and fatigue in juvenile polyarticular arthritis: Contemporaneous stressful events and mood as predictors. Arthritis Rheum 2005;52:1196-204.

32. Bennett SM, Huntsman E, Lilley CM. Parent perceptions of the impact of chronic pain in children and adolescents. Child Health Care 2000;29:147-59.

33. Hunfeld JA, Perquin CW, Duivenvoorden HJ, et al. Chronic pain and its impact on quality of life in adolescents and their families. J Pediatr Psychol 2001;26:145-53.

34. Tsao JCI, Meldrum M, Kim SC, Zeltzer L. Anxiety sensitivity and health-related quality of life in children with chronic pain. J Pain 2007;8:814-23.

35. Merlijn PBM, Hunfeld JAM, van der Wouden J, Hazebroek-Kampschreur AAJM, Koes BW, Passchier J. Psychosocial factors associated with chronic pain in adolescents. Pain 2003;101:33-4.

36. Gil KM, Carson JW, Porter LS, et al. Daily stress and mood and their association with pain, health-care use, and school activity in adolescents with sickle cell disease. J Pediatr Psychol 2003;28:363-73.

37. Hurtig AL, Koepke D, Park KB. Relation between severity of chronic illness and adjustment in children and adolescents with sickle cell disease. J Pediatr Psychol 1989;14:117-32.

38. Barbarin OA, Whitten CF, Bonds SM. Estimating rates of psychosocial problems in urban and poor children with sickle cell anemia. Health Soc Work 1994;19:112-9.

39. Hjern A, Alfven G, Östberg V. School stressors, psychological complaints and psychosomatic pain. Acta Paediatr 2008;97:112-7.

40. Anttila PA, Sourander A, Metsähonkala L, Aromaa M, Helenius H, Sillanapää M. Psychiatric symptoms in children with primary headache. J Am Acad Child Adolesc Psychiatry 2004:43:412-9.

41. Gold NR, Issenman R, Roberts J, Watt S. Well-adjusted children: An alternate view of children with inflammatory bowel disease and functional gastrointestinal complaints. Inflamm Bowel Dis 2000;6:1-7.

42. Campo JV, Bridge J, Ehmann M, et al. Recurrent abdominal pain, anxiety, and depression in primary care. Pediatrics 2004;113:817-24.

43. Karwautz A, Wöber C, Lang T, et al. Psychosocial factors in children and adolescents with migraine and tension-type headache: A controlled study and review of the literature. Cephalalgia 1999;19:32-43.

44. Mullick MSI, Nahar JS, Haq SA. Psychiatric morbidity, stressors, impact, and burden in juvenile idiopathic arthritis. J Health Popul Nutr 2005;23:142-9.

45. Sandstrom MJ, Schanberg LE. Brief report: Peer rejection, social behavior, and psychological adjustment in children with juvenile rheumatic disease. J Pediatr Psychol 2004;29:29-34.

46. Kaminsky L, Robertson MD, Dewey D. Psychological correlates of depression in children with recurrent abdominal pain. J Pediatr Psychol 2006;31:956-66.

47. Metsähonkala L, Sillanpää M, Tuominen J. Social environment and headache in 8- to 9-year-old children: A follow-up study. Headache 1998;38:222-8.

48. Claar RL, Walker LS. Maternal attributions for the causes and remedies of their children's abdominal pain. J Pediatr Psychol 1999;24:345-54.

49. Larsson B, Sund AM. Emotional/behavioural, social correlates and one-year predictors of frequent pains among early adolescents: Influences of pain characteristics. Eur J Pain 2007;11:57-65.

50. Roth-Isigkeit A, Thyen U, Stöven H, Schwarzenberger J, Schmucker P. Pain among children and adolescents: Restrictions in daily living and triggering factors. Pediatrics 2005;115:152-62.

51. Konijnenberg AY, Uiterwaal CSPM, Kimpen JLL, van der Hoeven J, Buitelaar JK, de Graeff-Meeder ER. 
Children with unexplained chronic pain: Substantial impairment in everyday life. Arch Dis Child 2005;90:680-6.

52. Guite JW, Logan DE, Sherry DD, Rose JB. Adolescent self-perception: Associations with chronic musculoskeletal pain and functional disability. J Pain 2004;8:379-86.

53. Flato B, Aasland A, Vandvik IH, Forre O. Outcome and predictive factors in children with chronic idiopathic musculoskeletal pain. Clin Exp Rheumatol 1997;15:569-77.

54. Walker LS, Claar RL, Garber J. Social consequences of children's pain: When do they encourage symptom maintenance? J Pediatr Psychol 2002;27:689-98.
55. Walker LS, Garber J, Greene JW. Complaints in pediatric patients: A prospective study of the role of negative life events, child social and academic competence, and parental s omatic symptoms. J Consult Clin Psychol 1994;62:1213-21.

56. Guell C. Painful childhood: Children living with juvenile arthritis. Qual Health Res 2007;17:884-92.

57. McGrath PJ, Walco, GA, Turk DC, et al. Core outcome domains and measures for the pediatric acute and chronic/recurrent pain clinical trials: PedIMMPACT recommendations. J Pain 2008;9:771-83. 


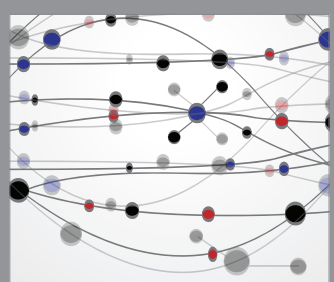

The Scientific World Journal
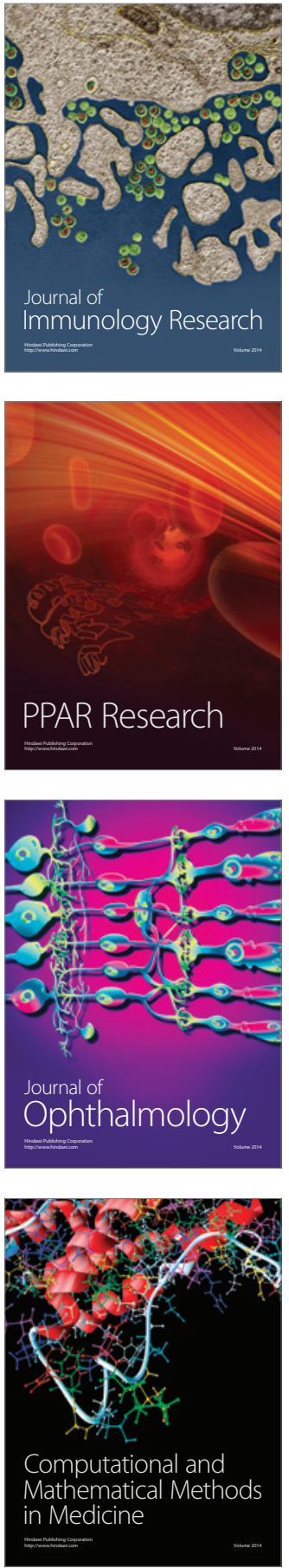

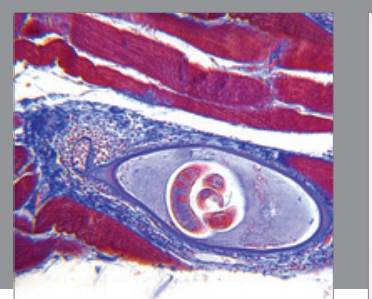

Gastroenterology Research and Practice

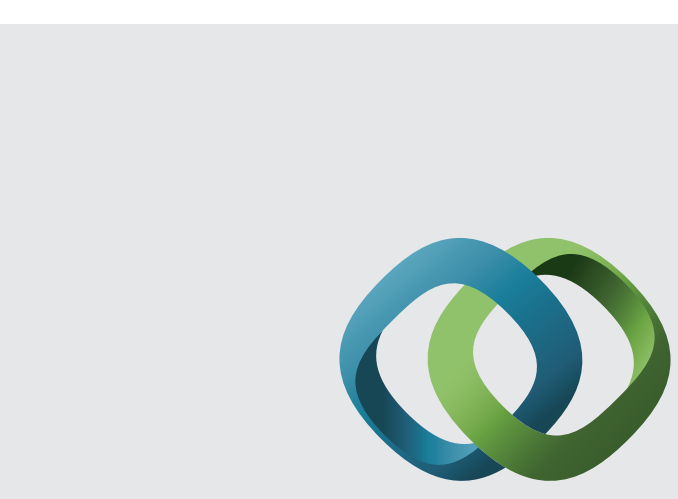

\section{Hindawi}

Submit your manuscripts at

http://www.hindawi.com
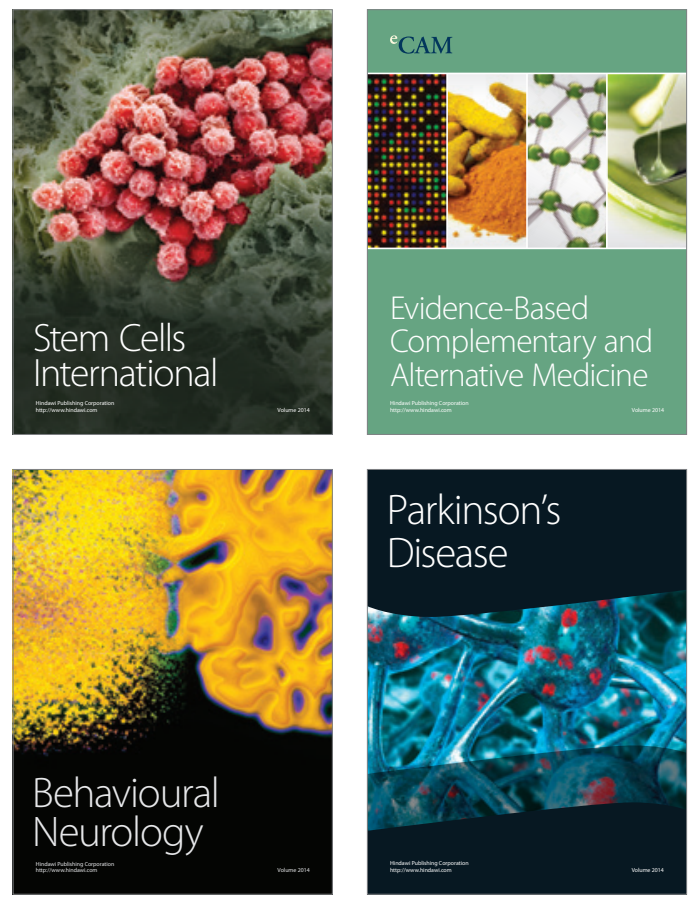
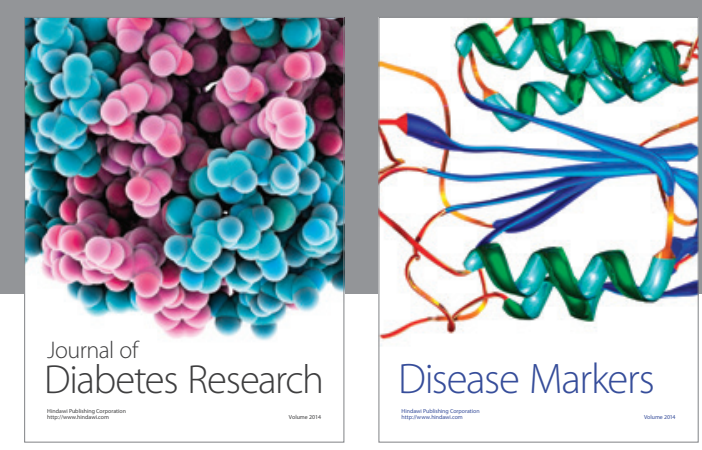

Disease Markers
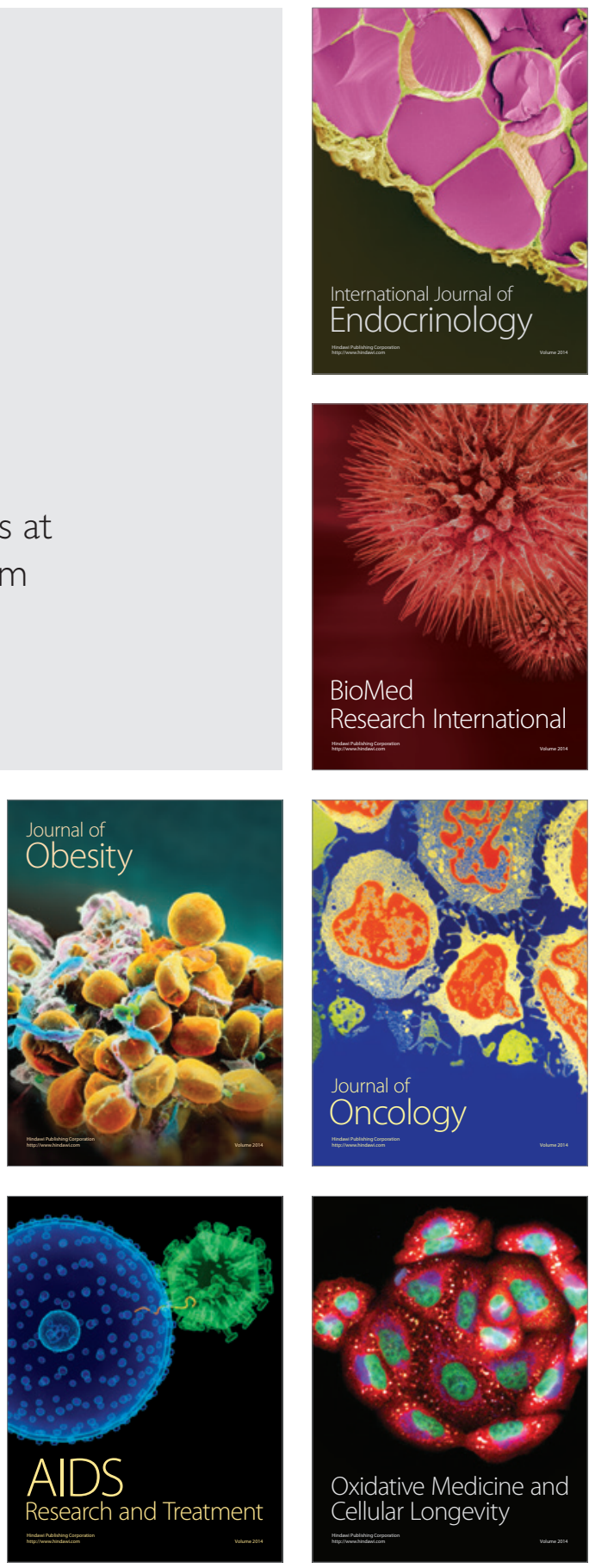